\title{
Pergeseran Kosakata Bahasa Indonesia pada Pengguna Instagram
}

\author{
Rosdiana \\ Prodi Pendidikan Bahasa dan Sastra Indonesia, Fakultas Keguruan dan Ilmu \\ Pendidikan, Univesias Muhammadiyah Makassar \\ rosdiana@unismuh.ac.id
}

\begin{abstract}
Abstrak
Tujuan penelitian adalah untuk mendeskripsikan Pergeseran Makna Kosakata Bahasa Indonesia pada Pengguna Instagram . Jenis penelitian ini adalah penelitian deskriptif kualitatif. Teknik analisis data dalam penelitian ini menggunakan teknik deskriptif kualitatif yaitu menggambarkan kemudian mendeskripsikan serta mengungkapkan pergeseran makna kosakata dalam bahasa Indonesia sesuai kenyataannya dalam pemakaian bahasa.dalam penelitian ini , data kosakata yang mengalami pergeseran makna dikumpulkan kemudian dikelompokkan,sesuai dengan jenis pergeseran maknanya. Hasil penelitian menunjukkan bahwa pergeseran makna kosakata dalam bahasa Indonesia memiliki enam kategori yaitu generalisasi, spesialisasi, ameliorasi, peyorasi, sinestesia, dan asosiasi. Hal ini dapat dilihat dari berbagai macam caption instagram yang dibuat oleh para remaja. Pergeseran makna ini terjadi karena beberapa faktor seperti adanya maksud tertentu seperti peringatan dan pesan moral, relevansi kata dengan zaman, atau penghargaan yang ingin disematkan terhadap objek yang diikuti oleh kata tersebut. Penelitian ini diharapkan mampu menjadi referensi yang komprehensif bagi penelitian-penelitian ke depannya dan bagi masyarakat terkait dengan pentingnya memahami pergeseran makna agar tak terjadi salah penafsiran dan kesalahpahaman.
\end{abstract}

Kata Kunci: Pergeseran makna, kosakata, pengguna instagram

\section{Pendahuluan}

Pergeseran makna (juga disebut pergeseran makna, pengembangan makna, atau penyempitan makna) merupkan evolusi penggunaan kata-kata biasanya hingga tahapan makna modern menjadi sangat berbeda dari makna aslinya. Kata setiap kata dalam setiap bahasa dapat saja mengalami pergeseran makna sesuai dengan kebutuhan pemakaian bahasanya. Di dalam peristiwa interaksi verbal manusia selalu menggunakan kata di dalam suatu kalimat atau ujaran dari bahasa yang mereka gunakan.

Adapun contoh pergeseran makna kosakata yang misalnya kata wanita bermakna 'orang (manusia) dan perempuan yang merupakan dua kata yang bersinonim. Akan tetatapi, kedua kata tersebut mempunyai nilai rasa yang berbeda. Kata wanita dalam kamus Besar Bahasa Indonesia (2012: 1556) bermakna'perempuan dewasa' sedangkan kata perempuan dalam Kamus Besar bahasa Indonesia (2012:1054) bermakna 'orang (manusia) 
yang mempunyai vagina, dapat menstruasi, hamil, melahirkan dan menyusui. Jadi dikatakan bahwa kata perempuan memiliki makna atau nilai rasa yang rendah (kootasi kurang baik. Perbedaan nilai ini dapat dilihat dan dirasakan dalam pemakaian sehari-hari, misalnya sering orang mengatakan perempuan jalanan, tetapi jarang sekali didengar ungkapan wanita jalanan. Demikian juga sebaliknya sering dilihat dan dibaca dituliskan dharma wanita tetapi jarang sekali atau bahkan tidak pernah ditemukan tulisan dharma perempuan.

Hal ini diperjelas dari penelitian 1) Firnasari (2015) pergeseran makna kosakata bahasa Indonesia , 2) Hesti Retnosari (2013) pergeseran bahasa Jawa dialek Banyumasan di Kalangan remaja dalam berkomunikasi, 3) Hijriyani (2018) pergeseran bahasa Jawa di Desa Karyamukti Kecamatan Gelumbang Kabupaten Muara Enim, 4) Sahril (2018) pergeseran bahasa daerah pada anak-anak di Kaula Tanjung Sumatra Utara dan ,5) Hasming (2009) pergeseran makna bahasa Bugis dialek Sinjai pada penutur bahasa Bugis Sinjaidi Makassar. Namun berbeda dengan rencana peneliti yang membahas pergeseran makna kosakata bahasa Indonesia . Maka peneliti menganalisis pergesesaran makna kosakata yang digunakan remaja pada Instagram karena banyak remaja yang menggunakan kosakata baru pada media sosial.

\section{Metode Penelitian}

Penelitian yang berhubungan dengan kebahasaan khususnya pergeseran makna kosakata bahasa Indonesia pada Instagram merupakan penelitian bahasa yang dirancang sebagai penelitian deskriptif kualitatif. Deskriptif karena peneliti berusaha meyajikan kenyataan-kenyataan secara objektif sesuai dengan kenyataan yang ditemukan di lapangan tentang pergeseran makna kosakata dalam media sosial Instagram. kualitatif karena peneliti berusaha menguraikan fakta atau fenomena pergeseran makna kosakata dalam bentuk kata. Penelitian kualitatif dapat diartikan sebagai penelitian yang menghasilkan data deskriptif, berupa kata-kata tertulis atau lisan dari orang-orang dan perilaku yang dapat diamati dari orang-orang yang diteliti (Moleong, 2010:4). Data penelitian ini adalah jenis-jenis pergeseran makna kosakata bahasa Indonesia (generalisasi, spesialisasi, ameliora, peyorasi, sinestesia, dan asosiasi) yang terdapat pada pengguna Instagram dikalangan remaja. Data yang diambil dalam penelitian ini adalah data tulis dan gambar, yaitu tulisan status dan komentar yang mereka upload dalam sosial media tersebut.

Teknik pengumpulan data yang digunakan dalam penelitian ini adalah sebagai berikut:

1. Teknik observasi ini digunakan untuk mengamati pergeseran kosakata pengguna isntagram pada kalangan remaja dengan bebas, sehingga diharapkan hasil penelitian ini akan obyektif. Di dalam penelitian ini menggunakan observasi non partisipan. Observasi non partisipan adalah dimana observer tidak ikut di dalam kehidupan orang yang akan 
diobservasi, dan secara terpisah berkedudukan selaku pengamat. Di dalam hal ini observer hanya bertindak sebagai penonton saja tanpa harus ikut terjun langsung ke lapangan.

2. Teknik baca yaitu dengan membaca setiap status dan komentar informan yang diketik dan diunggah ke dalam media sosial instagram.

3. Teknik dokumentasi dengan memfoto status dan komentar informan melalui layar smartphone. Untuk mendapatkan bahasa tulis yang merupakan pergeseran kosakata.

Teknik analisis data dalam penelitian ini menggunakan teknik deskriptif kualitatif yaitu menggambarkan kemudian mendeskripsikan serta mengungkapkan pergeseran makna kosakata dalam bahasa Indonesia sesuai kenyataannya dalam pemakaian bahasa.dalam penelitian ini , data kosakata yang mengalami pergeseran makna dikumpulkan kemudian dikelompokkan,sesuai dengan jenis pergeseran maknanya. Setelah dilakukan pengelompokkan data tersebut kemudian di analisis bentuk pergeseran maknanya. Data yang diambil yaitu data tertulis pada status dan komentar dalam interaksi tidak langsung melalui perantara akun Instagram.

\section{Hasil dan Pembahasan}

Penelitian ini menggunakan caption instagram remaja sebagai sumber data utama yang akan dikategorisasi ke dalam 6 (enam) jenis pergeseran makna dalam bahasa Indonesia (Generalisasi, spesialisasi, ameliorasi, peyorasi, sinestesia, dan asosiasi) berdasarkan analisis yang dilakukan oleh peneliti. Dalam penelitian ini, peneliti menggunakan 5 (lima) data untuk masing-masing kategori yang ada, dengan total data keseluruhan adalah 30 data. Berdasarkan hasil penelusuran peneliti, ada 16 akun instagram yang dijadikan sebagai sumber data dalam penelitian ini yang dapat diuraikan dalam tabel 4.1 berikut ini. 
Tabel 4.1

Data Akun Instagram yang Dijadikan Sumber Data

\begin{tabular}{|c|c|c|}
\hline No. & Nama Akun Instagram & $\begin{array}{c}\text { Jumlah } \\
\text { Data } \\
\text { yang } \\
\text { Diambil }\end{array}$ \\
\hline 1 & @indahhkasim & 1 \\
\hline 2 & @muhrezaes & 9 \\
\hline 3 & @rusliyah.abd & 1 \\
\hline 4 & @irmawatiwahyuningsih & 1 \\
\hline 5 & @iinpratiwi29_ & 1 \\
\hline 6 & @nurhalisahusain & 2 \\
\hline 7 & @muh.ihsan_rajab & 1 \\
\hline 8 & @khairunnisanur3 & 1 \\
\hline 9 & @iinekaswtry & 1 \\
\hline 10 & @wawan_pasalli1109 & 3 \\
\hline 11 & @lianaamalia_ & 1 \\
\hline 12 & @ikhaa185 & 3 \\
\hline 13 & @finnamel & 1 \\
\hline 14 & $@$ @tarantula.ra07 & 1 \\
\hline 15 & @kiki.indrawati27 & 2 \\
\hline 16 & @anniisa7462 & 1 \\
\hline & Total & 30 \\
\hline
\end{tabular}

Pada sub-bab pembahasan ini, akan dibahas mengenai motivasi atau faktor yang mempengaruhi terjadinya pergeseran makna dan apa tujuan yang ingin dicapai dari pergeseran makna tersebut.

1. Generalisasi

Pergeseran Makna pada Kata "Indah", 'Tujuan", "Mampus", "Terlambat", dan "Berharga"

Sejak kecil kita mengenal kata "indah" sebagai penggambaran suatu pemandangan, entah berupa pegunungan atau lautan. Namun kini, kata "indah" ini mengalami pergeseran makna secara luas namun tetap tidak menanggalkan makna awalnya sebagai suatu keelokan.. Selanjutnya pada kata "tujuan" yang sejak dahulu identik dengan ke mana kendaraan atau keberangkatan akan berakhir, namun kini dapat digunakan untuk menggambarkan keinginan masa depan yang tetap bermakna dengan arah. Kata ketiga yang akan dibahas yakni terkait dengan kata "mampus" yang sejatinya tidak ada dalam KBBI. Kata "mampus" adalah kata serapan dari bahasa Betawi yang bermakna tumbang atau kalah yang kini digunakan secara luas oleh masyarakat.

Selanjutnya terkait dengan kata "terlambat" yang selama ini dimaknai sebagai tindakan tidak tepat waktu dalam menghadiri sebuah acara atau pertemuan. Saat ini, kata "terlambat" digunakan untuk berbagai hal termasuk sebagai kata yang mewakili pesan moral. Terakhir, kata "berharga" yang berkata dasar "harga" yang biasanya dilekatkan pada sesuatu yang bisa dinilai dengan uang atau benda setara lainnya. Pergeseran maknan kemudian 
membuatnya digunakan untuk hal lain, bahkan untuk mendeskripsikan sebuah jalinan.

2. Spesialisasi

Pergeseran Makna pada Kata "Juara", "Senior", "Emak", "Sarjana", dan "Olahraga"

Pertama, kata "juara" yang sempat digunakan sebagai kata umum untuk menggambarkan posisi sesuatu dalam kehidupan atau pandangan seseorang. Namun, hal tersebut dianggap kurang relevan sehingga kini kata "juara" kembali dimaknai sebagai memenangkan suatu pertandingan, kompetisi, atau hal lain yang sejenis yang ditandai dengan piala, medali, atau penghargaan lainnya. Kedua yakni kata "senior" yang dulunya sempat digunakan untuk menghormati orang yang lebih berilmu atau berkemampuan lebih meskipun jenjang pendidikan atau kariernya lebih dibawah. Kini kata "senior" kembali disempitkan maknanya sebagai sebuah bentuk penghargaan kepada mereka yang memiliki jenjang pendidikan atau karier yang lebih tinggi. Ketiga yakni kata "emak" yang merupakan kata serapan dari bahasa Betawi yang bermakna sama dengan "ibu" dulu bisa dimaknai sebagai wanita yang berjasa dalam hidup kita meskipun tidak melahirkan kita. Kata "emak" kini kembali kepada esensinya sebagai wanita yang melahirkan kita sebagai bentuk penegasan siapa sosok Ibu sebenarnya.

Selanjutnya kata "sarjana" yang dulu sempat digunakan secara umum untuk menggambarkan orang yang cerdas, namun kini hanya dilekatkan bagi orang yang berhasil menyelesaikan pendidikan pada jenjang pendidikan strata satu (S1). Terakhir adalah kata "olahraga" yang dulunya bisa digunakan untuk menggambarkan segala aktivitas yang mengeluarkan keringat seperti membersihkan rumah dan sebagainya, namun hal itu dianggap tidak relevan sehingga kini benar-benar dimaknai sebagai kegiatan berolahraga (bermain sepakbola, basket, dan cabangolahraga lainnya).

3. Ameliorasi

Pergeseran Makna pada Kata "Kopi", "Saudara", "Sendiri", "Berjuang", dan "Langit"

Sebuah kata tentu memiliki makna dan makna itu bisa meningkat seiring dengan perkembangan zaman dan kebutuhan. Dalam kata "kopi" yang identik sebagai minuman penghilang kantuk atau stress, kini dimaknai sebagai minuman yang bisa menghilangkan rasa sepi. Hal ini dikarenakan saat ini "kopi" dianggap dapat membuat orang ngumpul dengan ajakan ngopi dan dipertegas dengan kehadiran warung-warung kopi (kafe) yang identik dengan keramaian dan tempat berkumpul. Selanjutnya ada kata "saudara" yang mulanya hanya dimaknai sebagai orang yang lahir dari rahim yang sama dengan kita, kini digunakan sebagai sebuah kata atau sapaan penghargaan kepada orang-orang yang sangat akrab atau berpengaruh besar dalam hidup seseorang.

Ketiga, kata "sendiri" yang dalam keseharian kita identik dengan tidak bersama dengan siapa-siapa di suatu tempat. Seiring perkembangan zaman kata "sendiri" tidak lagi dimaknai hanya berdasarkan latar tempat, tetapi juga bisa dimaknai dengan latar waktu dan status seseorang. Keempat, "berjuang" 
yang berkata dasar "juang" yang sejak dahulu digambarkan sebagai suatu upaya untung memenangkan perang. Kata "berjuang" kini tidak hanya disandingkan dengan peperangan namun juga disandingkan dengan kehidupan. Kata "berjuang" dianggap mampu memberikan semangat lebih dalam setiap aktivitas apapun.

Terakhir, terkait dengan kata "langit" yang selama ini hanya dimaknai sebagai ruang tak terbatas yang berada di atas bumi atau sebagai tempat beradanya matahari, planet, bulan, dan benda-benda lainnya. Kini, penggunaan kata "langit" tidak hanya sebatas pada pemaknaan tersebut. "Langit" kini dimaknakan lebih dari itu; sebagai patokan mengejar impian, dan paling prestisius dianggap sebagai kedudukan Tuhan yang Maha Kuasa.

4. Peyorasi

Pergeseran Makna pada kata "Tanah", "Merah", "Luka”, "Setan", dan "Terakhir"

Selain peningkatan makna, ada juga kata yang mengalami penurunan makna. Bukan berarti maknanya benar-benar turun, hanya saja kata tersebut dapat mengalami penurunan makna jika digunakan untuk merepresentasikan sesuatu yang tidak baik atau sebuah pesan moral Seperti beberapa kata berikut.

Pertama, kata "tanah" yang selama ini hanya kita maknai dengan tempat kita berpijak, tempat kita hidup, dan pemaknaan lainnya yang serupa. Tanah kini dapat digunakan sebagai pesan moral seperti pada kalimat "kita semua akan kembali ke tanah" yang bisa dimaknai sebagai mati. Kedua adalah kata "merah" yang selama ini hanya dikenal sebagai sebuah warna. Kini, dapat dilekatkan pada objek non warna seperti pada kalimat "zona merah" yang berarti berbahaya. Penuruan makna pada kata "merah" ini merujuk pada warna darah, sehingga dijadikan sebagai sebuah makna peringatan.

Selanjutnya ada kata "luka" yang dulu hanya dimaknai sebagai keadaan di mana lapisan kulit mengalami pendarahan akibat goresan, irisan, atau benturan. Sekarang kata "luka" banyak digunakan oleh masyarakat sebagai untuk menggambarkan sebuah keadaan luka yang tidak berdarah, dalam hal ini terkait hati dan jiwa. Keempat, kata "setan" sebagai kata yang dimaknai sebagai makhluk yang diusir Tuhan dari surga dan senantiasa menggoda manusia kepada kemaksiatan. Namun secara peyoratif, kata "setan" kini tidak lagi hanya dilekatkan pada wujud yang sesungguhnya, namun dilekatkan juga pada manusia yang berperilaku seperti "setan" itu sendiri. Terakhir, adalah kata "terakhir" itu sendiri yang secara umum dimaknai sebagai paling belakang atau paling telat. Namun sekarang banyak digunakan sebagai pesan moral seperti dalam kalimat "momen terakhir" yang menggambarkan suatu perpisahan atau bahkan kematian.

5. Sinestesia

Pergeseran Makna pada Kata "Remi", "Kursi Kosong”, "Atap", "Balon" dan "Matahari" 
Pergeseran makna kadangkala membutuhkan penafsiran panca indera yang lebih dari sekedar penafsiran biasa berdasarkan wujudnya. Beberapa hal ini terjadi pada kata-kata berikut.

Kata "remi" tentu identik permainan yang menggunakan kartu remi seperti joker atau poker yang didalamnya terdiri dari berbagai jenis kartu seperti joker dan As. Pergeseran maknanya terjadi ketika dilekatka pada kalimat perumpaan seperti "layaknya kartu remi, kita harus menjadi kartu As" yang berisikan sebuah pesan moral. Selanjutnya adalah kata "kursi kosong" yang pastinya langsung dimaknai oleh indera sebagai kursi tanpa orang yang mendudukinya. Namun, maknanya berubah jika digunakan untuk menggambarkan hal lain seperti pada kalimat "berfikir bersama kursi kosong" yang bermakna berfikir sendirian.

Ketiga kata "Atap"yang identik dengan penutup atau bagian atas rumah, yang kini banyak dimaknai lain pada berbagai bidang. Contohnya jika menggunakan kata "atap Sulawesi" yang bermakna puncak gunung tertinggi di Pulau Sulawesi. Kata lain juga yang bisa dimaknai secara sinestesia adalah "balon" yang selama ini dinilai oleh indera sebagai benda yang berisi gas yang banyak digunakan saat ada seremoni. Pergeseran maknanya terjadi jika dilekatkan pada kalimat kiasan seperti "Haruskah aku jadi balon agar kau pegang erat-erat?". Terakhir, yaitu kata "Matahari" yang tentu tidak asing bagi indera kita sebagai sumber cahaya dan panas utama bagi bumi disiang hari dan sebagai pusat dari galaksi bima sakti dalam kajian sains. Makna sebagai sebagai sumber cahaya dan panas utama inilah yang kemudian mengalami pergeseran makna secara sinestesia seperti pada kata "meneladani matahari". Artinya, jadilah seperti matahari yang terus menyinari dan menghangatkan tanpa pamrih kepada bumi.

6. Asosiasi

Pergeseran Makna pada Kata "Miniatur Alam Semesta", "Matahari menjaga Bumi", "Keluarga Cemara", dan "Mawar yang Membahagiakan"

Pergeseran makna secara asosiasi terjadi karena adanya pemaknaan sifat yang dapat mewakili kata atau kalimat lain seperti pada beberapa kata berikut.

Pertama "miniatur alam semesta", dimana kata "miniatur" ini bermakna sebagai gambaran atau representasi. Contoh dari pergeseran makna ini adalah "manusia adalah miniatur alam semesta", yang berarti "manusia" dapat merepresentasikan alam semesta sangat luas ini, dan itu digambarkan dalam kata "miniatur alam semesta". Kedua "Matahari menjaga Bumi" yang merupakan asosiasi dari manusia yang harus menjaga manusia atau dalam hal ini berkorelasi dengan sebuah hubungan diantara manusia. Penggambaran tersebut dapat kita cermati pada contoh redaksi kalimat "jadilah seperti matahari yang menjaga bumi, terus menerus tanpa pamrih" yang merupakan sebuah pesan moral.

Ketiga, "keluarga cemara" yang kini banyak dimaknai sebagai perwujudan keluarga yang bahagia. Sejatinya, "cemara" hanyalah sebuah tanaman, namun selama ini digunakan sebagai lambang kebahagiaan 
sehingga disandingkan dengan kata "keluarga". Keempat, "mawar yang membahagiakan", yang kurang lebih dimaknai sama seperti pohon cemara meskipun wujudnya adalah tanaman. "Mawar" selama ini dilambangkan sebagai lambang keromantisan, di mana hal ini juga dimaknai sebagai sumber kebahagiaan. Terakhir, terakhir "jadilah seperti kopi". Tak mungkin manusia menjadi "kopi", tetapi makna filosofis dibalik kata "kopi" itulah yang ingin diimplementasikan. "Kopi” pada umumnya memang pahit dan kita pun tidak bisa mendustai lidah kita terkait hal tersebut. Kejujuran inilah ynag ingin diterapkan dalam hidup kita sesuai dengan pesan moral yang ada dalam kata "kopi" tersebut.

\section{SIMPULAN}

Setelah melakukan kategorisasi dan analisis terhadap data-data yang dikumpulkan, ada beberapa kesimpulan yang dapat ditarik dalam penelitian ini. Kesimpulan ini ditarik berdasarkan apa yang ditemukan dan dipahami peneliti terkait pergeseran makna kosakata yang kemudian dikaitkan dengan landasan teori yang digunakan. Kesimpulan tersebut kemudian diuraikan sebagai berikut.

Pertama, pergeseran makna secara generalisasi terjadi karena adanya keluasan makna yang dapat merepresentasikan objek atau hal lain. Contohnya seperti "indah", "tujuan", "mampus", "terlambat", dan "berharga". Kedua, pergeseran makna secara spesialisasi terjadi karena adanya penilaian terhadap relevansi makna masa kini dan makna awal yang berbeda, di mana makna awal dianggap jauh lebih relevan dan pas. Contohnya seperti "sarjana", "juara", "senior", "emak", dan "olahraga". Ketiga, pergeseran makna secara ameliorasi terjadi ada kata yang dianggap bisa bermakna yang lebih baik lagi sehingga harus mengalami peningkatan derajat makna dari makna awal. Biasanya hal ini terjadi pada kata yang berhubungan dengan pesan moral. Contohnya seperti "kopi", "saudara", "sendiri", "berjuang", dan "langit". Keempat, pergeseran makna secara peyorasi terjadi bilamana suatu kata dianggap dapat dianalogikan sebagai sesuatu yang mrnggambarkan hal buruk atau dapat menjadi peringatan. Contohnya seperti "tanah" "garis merah", "luka", "setan", dan "terakhir". Kelima, pergeseran makna secara sinestesia terjadi karena adanya penilaian indera yang berbeda dengan makna yang ingin disampaikan seperti dalam "kursi kosong", "menapak atap", "kartu remi", "meneladani matahari", dan "haruskah aku meletus?".

\section{Daftar Pustaka}

Arnawa, Nengah. 2016. Pergeseran Kosakata Bahasa Bali Ranah Pertanian:

Studi Linguistik Kebudayaan. Jurnal. Vol. 28 No. Di unduh 15 Januari 2020. Dari http://repo.ikippgribali.ac.id.

Citra. (1999).Penguasaan Kosakata Bahasa Indonesia Kelas III Batara Gowa Singguminasa. Skripsi. Ujung Pandang: FPBS IKIP Ujung Pandang.

Danie, Julianus Akun. 1987. Kajian Geografi Dialek Minahasa Timur Laut.

Desertasi pada Universitas Indonesia, Jakarta. 
Firnasari. 2016. Pergeseran Makna Kosakata Bahasa Indonesia Harian Teribun Timur. Skripsi. Tidak Diterbitkan.

Fitriyadi, Rizky. 2014. Pengaruh Penguasaan Kosa Kata dan Tata Bahasa Indonesia Terhadap Kemampuan Menulis Eksposisi Siswa Kelas x

SMA Negeri Se Kota Yogyakarta. Skripsi: 'Tidak Diterbitkan.

Hijriyani.2018. Pergeseran bahasa Jawa di Desa Karyamukti Kecematan Gelumbang Kabupaten Muara Enim. Skripsi: Tidak Diterbitkan.

Irwansyah. 2011. Corporate and Marketing Communication. Jakarta: Puskombis Universitas Mercu Buana

Keraf, G. (2009).Tata Bahasa Indonesia.Ende: Nusa Indah.

Khaer, Fajrul. 2017. Implikasi Visual Media Instagram Terhadap Peggunaan Ragam Bhasa Indonesia. Skripsi: tidak Diterbitkan.

Kridalaksana, H. (1993). Kamus Linguistik. Jakarta: Gramedia Pustaka Utama.

Martono. (1990). Kosakata Bahasa TulangMamak. Jakarta. Depdibud.

Masyhitah. 2017. Pergeseran Bahasa Bugis Dialek Barru Pada Penutur Bahasa Bugis Dialek Barru di Makassar (Tinjauan Sosiolinguistik). Skripsi: Tidak Diterbitkan.

Moleong, Lexy J. 2010. Metodologi Penelitian Kualitatif. Bandung: Remaja Rosda Karya.

Munirah \& Hardian.2016. Pengaruh Kemampuan Kosakata dan Struktur

Kalimat Terhadap Kemampuan Menulis Paragraf Deskripsi Siswa SMA.Jurnal.Vol 16 No 1. Di unduh 07 Januari 2002, dari http://dx.doi.org./10.17509/bs jpbs.v1512.

Nurul Irawan, Yulia. 2013. Pergesran bahasa Mandarin dialek Hokkian dalam keluarga etnis Cina Benteng di kelurahan Sukasari kota Tanggerang. Skripsi: Tidak Diterbitkan.

Pateda, Mansoer. 2010. Semantik Lesikal. Jakarta:Rineka Cipta.

Prihatningsih, Witanti. (2017). Motif Penggunaan Media Sosial Instagram di Kalangan Remaja. Jakarta: 7 januari 2020 dari http://journal.budiluhur.ac.id.

Rahma Putri, Devita. 2016, Artikel Tentang Instagram. Diambil dari : http://putridevits.blogspot.co.id/2016/04/artikel-tentanginstagram.html (07 April 2016).

Retrosari, Hesti. (2013). Pergeseran Bahasa Jawa Dialek Banyumasan Di Kalangan Remaja Dalam Berkomunikasi. Skripsi: Tidak Diterbitkan.

Sahril. (2018). Pergeseran Bahasa Daerah pada Anak-Anak di Kuala Tanjung Sumatera Utara, Ranah: Jurnal Kajian Bahasa, 7 (2), 210-228. doi: https://doi.org/10.26499/rnh.v7i2.571 Sumarsono dan Paina

Partana. 2002. Sosiolinguistik. Yogyakarta: Penerbit Sabda.

Setiawati, Sulis. 2016. Penggunaan Kamus Besar bahasa Indonesia (KBBI) dalam Pembelajaran Kosakata Baku dan tidak Baku pada Siswa Kelas

IV SD. Jurnal. Vol 2.i1 (44-45). Di unduh 15 Januari 2020. Dari http://dx.doi.org/10.22202/JG.2016.v2i1.1048.

Soedjito. 1992. Kosakata Bahasa Indonesia. Jakarta: Gramedia Pustaka Utama. 
Jurnal Onoma: Pendidikan, Bahasa dan Sastra PBSI FKIP Universitas Cokroaminoto Palopo

Volume 7 Nomor 1 Tahun 2021
ISSN 2443-3667 (Print)

ISSN 2715-4564 (Online

Soekesi. 1994. Tata Istilah Indonesia. Jakarta: Depdikbud.

Tarigan. 1986. Pengajaran Kosakata. Bandung: Angkasa. Soedjito. 1992. Kosakata Bahasa Indonesia. Jakarta: Gramedia Pustaka Utama.

Yusuf, Muri. 2014. Metodologi Penelitian Kuantitatif, Kualitatif \& Gabungan.Jakarta. 